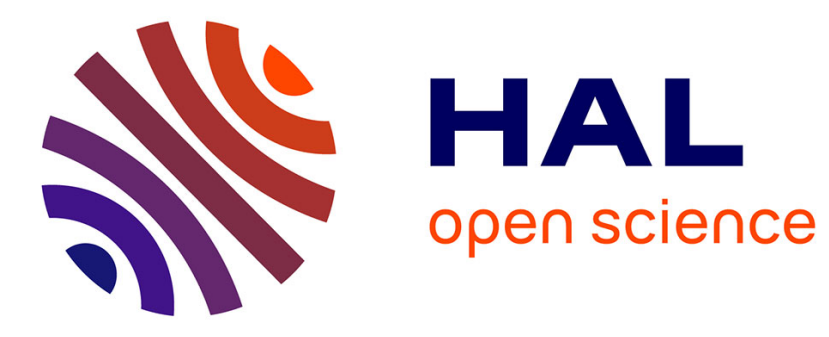

\title{
The Child Reader's Playful Adventures in Wonderland
}

Virginie Iché

\section{To cite this version:}

Virginie Iché. The Child Reader's Playful Adventures in Wonderland. Deszcz-Tryhubczak, Justyna; Kalla, Irena Barbara. Children's Literature and Intergenerational Relationships, Springer International Publishing, pp.19-33, 2021, 978-3-030-67699-5. 10.1007/978-3-030-67700-8_2 . hal-03209928

\section{HAL Id: hal-03209928 https://hal.science/hal-03209928}

Submitted on 27 Apr 2021

HAL is a multi-disciplinary open access archive for the deposit and dissemination of scientific research documents, whether they are published or not. The documents may come from teaching and research institutions in France or abroad, or from public or private research centers.
L'archive ouverte pluridisciplinaire HAL, est destinée au dépôt et à la diffusion de documents scientifiques de niveau recherche, publiés ou non, émanant des établissements d'enseignement et de recherche français ou étrangers, des laboratoires publics ou privés. 
Virginie Iché, Université Paul Valéry Montpellier, France

The Child Reader's Playful Adventures in Wonderland

\begin{abstract}
This chapter interrogates the widespread assumption that the Alice books engage in a game with the virtual (child) reader. A close analysis reveals that the virtual child reader constructed in both Alice books is actually extremely constrained. Carroll's virtual child reader, then, is more akin to Eco's Model Reader, whose participation is pre-constructed by the author, than to Iser's implied reader, who truly communicates with the text. Accordingly, although the virtual child reader is apparently invited to give in to what Caillois calls paidia (the impulsive manifestation of a play instinct), she is actually tricked into strictly adhering to ludus (the need to conform to rules). I nonetheless show that real adult readers seem to be able to take on the role of Impostor Readers - a term coined after Lecercle's theory of imposture (1999) - and imagine unforeseen realizations of the text, thereby combining paidia and ludus. Child readers could then be thought to be able to similarly playfully circumvent the rules laid out by Carroll's textual structures / strictures.
\end{abstract}

Keywords: Lewis Carroll, reader-response theory, Model Reader, Impostor Reader, paidia, ludus

Stuart Dodgson Collingwood, Lewis Carroll's nephew, was the first to write about his uncle's taste for inventing games and his propensity to entertain his audience (1898). It is then no wonder that I have argued (2015), after Kathleen Blake (1974), Robert Polhemus (1992) and Jan Susina (2010) among others, that play and games are crucial to the understanding of Alice's Adventures in Wonderland (1865) and Through the Looking-Glass (1871). Some critics have also made the more specific claim that the Alice books engage in a game with the reader. Donald Sutherland claims that Lewis Carroll was "deliberately setting linguistic 'brain-teasers' for his readers to puzzle over" (15) and consequently "quite literally playing games with his 
readers" (16); Blake mentions "a playing-with-the-reader attitude" in the Alice books (15); Polhemus posits that the reader plays with language as much as Carroll does (369).

This assumption raises a number of questions: how can we say that a reader plays with a text, and what type of games can she play? The critics mentioned above do not clarify explicitly what they mean when they state that the reader is invited to play with the text, but they seem to implicitly suggest that she is encouraged to be an active reader, ready to playfully collaborate with the textual structures she encounters. Though Brian Sutton-Smith asserts that "play's definition must be broad rather than narrow, including passive or vicarious forms as well as the active participant forms" $(1997,218)$, it is interesting to note the implicit emphasis on (and limitation to) active forms of play in the field of general literature and/or children's literature - this probably stemming from psychoanalytic visions of play as empowerment (see Freud's theorization of the role of the game "Fort-Da" in the child's development of her sense of mastery and ego formation). Being an active reader implies being actively implicated in the meaning-building process involved in the reading of a book.

Critics suggesting that readers are playfully interacting with the books they are reading consequently seem to hint at a dialectic relationship between the text and the reader, much like Wolfgang Iser in The Act of Reading (1978) or Umberto Eco in Lector in Fabula (1985). According to Iser, the act of reading relies on the interaction between a text and the reader's imaginative and perceptive faculties. Gaps in the text, namely "blanks" and "negations," spur the reader into forming creative interpretations. Iser's implied reader, as he calls it, therefore truly communicates with the text, and to use Iser's own terms, shares "the game of imagination" with the author (108). Iser insists on the active role of the reader, who needs to be productive in order to really enjoy the reading process in full (108). In that sense, one could argue that Iser's implied reader fully experiences the two aspects of play identified by Roger Caillois in his sociological analysis of games and play (1958); that is, paidia, the impulsive manifestation of a play instinct, and ludus, the need to conform to rules ${ }^{1}$ (75). While Iser's implied reader has to respect the unobtrusive rules (gaps, blanks, negations) left by the author, she also has to inventively interact with the text—-thereby giving in to paidia.

\footnotetext{
${ }^{1}$ French philosopher Colas Duflo identifies a seemingly similar tension at the core of play in his book Jouer et Philosopher (1997). He coins the concept of "legafreedom" which helps him define play: for him, indeed, "playing consists in inventing freedom within and thanks to the bounds of the law" (57, my translation). Duflo's definition though ultimately relies on a conservative vision of play - freedom always remaining within the confines of the law. I believe Caillois's proposed continuum between paidia and ludus is more encompassing, as it does not favor one pole over the other - some activities can be more "ludic" than "paidian" others more "paidian" than "ludic" but all of them will be defined as "playful," provided they are both "ludic" and "paidian."
} 
Like Iser, Umberto Eco repeatedly emphasizes the need to re-evaluate the role of the reader instead of considering that her interpretive intervention is a methodological impurity. He underscores the key-role of what he too calls "blanks" and the reader's involvement in the reading process. However, a closer look at his definition of the reader's role reveals how he circumscribes and ultimately limits it. For Eco, "the text is a lazy machine that exacts an obstinate cooperative work on the part of the reader in order to fill in a series of blank spaces of unsaid or already-said missing elements" (27, my translation). Eco's blanks are very different from Iser's: they are more localized and specific, and appear (so to speak) when an author leaves some elements unsaid for her sentences not to be redundant or ponderous (64). The reader who comes across such blanks has little difficulty remembering expressions already mentioned above in the text or identifying presuppositions and common knowledge left unsaid. Although Eco claims to reassert the role of the reader, he ultimately highlights the supremacy of the text, which needs the reader indeed, but only to make it work just as it is supposed to work. As Eco puts it, the author "will plan a Model Reader, able to cooperate in the realization of the text just as the author arranged for him to do, and able to deal interpretively with a text in the same way as he dealt generatively with it," that is to say in producing it $(68$, my translation). It therefore seems that, unlike Iser's implied reader, Eco's Model Reader does not give in to Caillois's paidia, the impulsive manifestation of a play instinct, but is actually tricked into strictly adhering to $l u d u s$, the need to conform to rules. Consequently, Eco's Model Reader cannot really play, as Caillois makes it clear that experiencing ludus without paidia is nothing but a "stopgap", meant only to stave off boredom (83). Real play relies on the tension between paidia and ludus.

Iser and Eco both emphasize the role of the virtual (i.e. implied or Model) reader, whose involvement is planned by the text, but never do they attempt or seem to think it desirable to describe the virtual reader in detail. Iser makes it clear that the implied reader is anticipated by the textual structure but can never really be defined (34). Perry Nodelman (2008) and Zohar Shavit (2012) do not contend otherwise, but have nevertheless famously argued that children's books construct and rely on two types of implied readers: adult readers - adults being (most of the time) the ones who buy children's books and are consequently held in mind, if not targeted, by authors - and, obviously, child readers. Roald Dahl was keenly aware of the possibility that some children's books actually address an adult audience: "What narks me tremendously is people who pretend they're writing for young children and they're really writing to get laughs from adults. [...] I refuse to believe that Carroll wrote Alice for that little girl" (Wintle and Fisher 110). Dahl's comment could lead us to infer that the implied reader of the Alice books 
is not really a child reader. However, Marah Gubar has convincingly argued that Carroll's main concern was the adult author-child reader relationship: "[a]s the opening poem intimates, he longs to conceptualize this liaison as dialogic and pleasurable for both parties" (97). ${ }^{2}$ Peter Hunt also asserts that "[t]hese books [Alice's Adventures in Wonderland and Through the Looking-Glass], chameleon-like, suffused with remorseless logic masquerading as nonsense, and nonsense masquerading as logic, are at their core about the relationship between adults and children" (37); reading the Alice books as an adult means we have to read them "in compliance with, or in tension with, the implied readership" (40). Raising the question of the implied reader of the Alice books will then shed (more) light on the relationship between the adult author and the implied child reader envisioned by Lewis Carroll.

In this chapter, I argue that although Alice's Adventures in Wonderland and Through the Looking-Glass are scattered with seemingly response-inviting strategies, hence apparently eliciting the virtual child reader's fully playful cooperation, these strategies turn out to be response-controlling expressions, limiting the child reader's playfulness. Carroll's virtual child reader consequently seems to be more akin to Eco's Model Reader than to Iser's implied reader. Thanks to a qualitative analysis of the actual responses given by some of the adult members of what Stanley Fish would call the interpretive community of the Alice books, I nonetheless suggest that real adult readers seem to be able to take on the role of Impostor Readers - a term coined after Jean-Jacques Lecercle's theory of imposture in Interpretation as Pragmatics (1999) - and imagine unforeseen realizations of the text, thereby fully combining the two aspects of play defined by Caillois, paidia and ludus. Child readers could therefore be thought to be able to similarly playfully circumvent the rules laid out by Carroll's textual structures / strictures.

\section{Seemingly Response-Inviting Strategies}

Though the narrator of the Alice books hardly ever says "I," he abundantly addresses the extradiegetic narratee, with which, as Gérard Genette argues in more general terms in his book on narratology, the reader can easily identify (266). The extradiegetic narratee is never depicted in so many words in the core of the Alice books, but the thresholds of both volumes lead us to

\footnotetext{
${ }^{2}$ Gubar nonetheless shows how Carroll himself doubts the possibility of such a collaboration-the power relationship between adults and children being hard to deconstruct, and children being always more or less consciously coerced by adults and children's literature. For Gubar, there is hope in "reciprocal aggression" only (97-98).
} 
think of her as a child ${ }^{3}$ - the same type of child who not only inspired but also participated in the creation of Alice's Adventures in Wonderland, if the prefatory poem to that book is to be believed. And the extradiegetic narratee of the Alice books seems to be not a mere structural necessity, but a true participant in the Carrollian tales. At the beginning of Alice's Adventures in Wonderland, the narrator famously addresses her in these words: "fancy, curtseying as you're falling through the air! Do you think you could manage it?" (5), while Through the Looking-Glass ends with the following question: "Which do you think it was?" (222). In these examples (and many others), the reader seems to be explicitly invited to take at least some part in the narration. Björn Sundmark even asserts that "to read the Alice stories is to participate in an act of performance" (153).

Not only do the Alice books feature many similar direct questions that the child reader is seemingly encouraged to answer, but they also abound with other outwardly responseinviting strategies, and in particular with blanks. The blank lines inserted before and after the Humpty Dumpty nursery rhyme in chapter VI of the original edition of Through the LookingGlass (115) disconnect the rhyme from the rest of the text, thereby inviting the reader to take some time to think about it and look for the solution to the Humpty Dumpty riddle. ${ }^{4}$ Similarly, the third chapter of Through the Looking-Glass ends with the following unfinished sentence, followed by a blank space: "So she wandered on, talking to herself as she went, till, on turning a sharp corner, she came upon two fat little men, so suddenly that she could not help starting back, but in another moment she recovered herself, feeling sure that they must be" (65). Not only is the sentence left hanging in midair, with no punctuation mark whatsoever, but the rest of the right-hand page is also intentionally left blank. ${ }^{5}$ This most astonishing blank, which exploits the page-turning mechanism, described as a "minor but inherently disruptive event" by Mou-Lan Wong (44), prompts the reader to try to finish the sentence and guess who these "two fat little men" are before actually turning the page and reading the title of the following chapter, which, incidentally, is the end of the truncated sentence left unfinished on page 65.

Finally, and this is by far the strategy that Carroll uses the most, many sentences and paragraphs end with a dash, which the reader is expected to replace with the missing expression. This first happens when Alice tries, to no avail, to confirm her identity by reciting her multiplication tables, and when she ends up reciting Wonderland multiplication tables: "Let

\footnotetext{
${ }^{3}$ An older child in Through the Looking-Glass, but still a child.

${ }^{4}$ The Opies remind us that the Humpty Dumpty nursery rhyme was originally a riddle although few people think of it as one now since Humpty Dumpty has become a popular nursery figure (252).

${ }^{5}$ This is definitely not a typographical error: Hancher (1985), Wong (2009), Jaques and Giddens (2013), Iché (2016) and have emphasized Carroll's meticulousness and extreme attention to the layout of his Alice books.
} 
me see: four times five is twelve, and four times six is thirteen, and four times seven is - oh dear!" (19-20). This happens again when Alice repeats the second verse of "Tis the voice of the sluggard", ${ }^{6}$ which she does not finish:

I passed by his garden, and marked, with one eye,

How the Owl and the Panther were sharing a pie:

The Panther took pie-crust, and gravy, and meat,

While the Owl had the dish as its share of the treat.

When the pie was all finished, the Owl, as a boon,

Was kindly permitted to pocket the spoon:

While the Panther received knife and fork with a growl,

And concluded the banquet by-(111)

These three strategies - the blank lines, the exploitation of the page-turning mechanism and the dashes - literally materialize the blanks previously mentioned and seem to invite the reader to give in to her paidian instincts and participate in the realization of Carroll's text. They seem, at first glance, to promote an active virtual child reader, always ready to communicate with the text he reads, in a word an implied reader, as Iser defines it in The Act of Reading.

\section{Yet Response-Controlling Expressions}

All these seemingly response-inviting structures are nevertheless deceptive and turn out to be response-controlling expressions. Instead of promoting a fully active child reader, Carroll's Alice books actually limit and circumscribe the child reader's action. The blanks Alice's Adventures in Wonderland and Through the Looking-Glass abound with are more akin to Eco's blanks (which result from the deletion of already-said or unsaid elements) than to Iserian blanks. Indeed, many of Carroll's blanks can be filled in with words or expressions already given in the co-text in the left-hand side and, as such, belong to the type of blanks seen by Eco as resulting from erasing "already-said" elements. The Humpty Dumpty riddle is a case in point. The answer, an egg, is given before the rhyme is recited. At the end of chapter V, Alice

\footnotetext{
${ }^{6}$ In the first edition of Alice's Adventures in Wonderland, the second verse was only composed of the first two lines of the eight-line verse quoted here. The full verse, which Carroll wrote for the theatrical version of Alice in 1886, was included in Alice's Adventures in Wonderland from that moment on. This quotation is therefore taken from The Annotated Alice.
} 
tries to grab an egg, which "seems to get further away the more [she] walk[s] towards it" (112), and, at the beginning of chapter VI, this egg gets "larger and larger, and more and more human" (113), until the girl eventually recognizes Humpty Dumpty. Only after this transformation does she repeat the original rhyme: at this point, the child reader does no longer need to look for an answer since it has already been given. The end of chapter III, which ends with the unfinished sentence "feeling sure that they must be" (65), is another case in point. The metrical shape of this passage seems to be a clue to help the reader fill in the blank with the right words, "Tweedledum and Tweedledee." ${ }^{7}$ However, this fill-in-the-blank game is not a game of imagination since the answer is given in advance by the narrator in the co-text in the left-hand side: "wherever the road divided, there were sure to be two finger-posts pointing the same way, one marked 'TO TWEEDLEDUM'S HOUSE,' and the other 'TO THE HOUSE OF TWEEDLEDEE"' (65). The child reader's task thus only consists in remembering the co-text in the left-hand side.

Other Carrollian blanks do not spur the child reader to look for a specific word or expression in the co-text, but rely on what Eco calls "unsaid elements" (27). They are nonetheless no harder to fill in, as the answers are made all-too-obvious by the co-text. This is the case with the Wonderland multiplication table, which can be very easily resolved although it initially appears to be very surprising. Anyone who has read the 1864 manuscript, Alice's Adventures under Ground, knows that in that version Alice does not leave the result of the last multiplication unsaid, as she says: "Let me see: four times five is twelve, and four times six is thirteen, and four times seven is fourteen —oh dear!" (14). Carroll's erasing the last result and replacing it with a dash for the 1865 version of Alice's adventures shows that the mathematical riddle in Alice's Adventures in Wonderland does consist in finding this specific answer, which is left unsaid in this version of Alice's adventures, but had been planned in advance. Anyone who has not read the 1864 manuscript though (namely, child readers, who would obviously not be familiar with that version of Alice's adventures) can also readily deduce from the fact that the results of the first two multiplications were twelve and thirteen that the result of the third multiplication will be fourteen. As Wittgenstein has shown in Philosophical Investigations (2009), it is possible to "understand" a series of numbers without being aware of the underlying formulae, just because the succession of numbers seems logical enough or easy enough (65-66e). Although this multiplication table is actually a sophisticated

\footnotetext{
${ }^{7}$ As Donald Reichertz puts it, the prose conclusion to this chapter "takes metrical shape and becomes the first line of an absolutely regular seven-syllable, four-beat trochaic couplet” (56).
} 
mathematical game in disguise, as Sophie Marret reminds us in her 1995 Lewis Carroll - De l'autre côté de la logique (162), it is not necessary to have advanced knowledge in mathematics to find the unique solution to the Wonderland multiplication table - the child reader can easily find the logical solution to this (seemingly) illogical multiplication table. Similarly, Alice's truncated version of the second verse of "Tis the voice of the sluggard" invites the reader to make the implicit and yet very much recognizable answer explicit. As Beverly Lyon Clark has noted in her article "Carroll's Well-Versed Narrative: Through the Looking-Glass" (1982), “guided by meter and rhyme, by our knowledge of panthers, by our knowledge that 'by' wants here to be followed by a verb ending in 'ing' - we can readily complete the line with 'eating the Owl'" (74). Once again, there is only one logical solution to the ending of this poem, and the reader's participation is very much circumscribed and limited to finding that solution. This shows both that Carroll's "blanks" are more similar to Eco's than to Iser's and that Carroll's reader, who is invited to strictly follow the ludic rules of Carroll's game, is closer to Eco's Model Reader than to an Iserian "implied reader."

\section{The Playful Revenge of the Impostor Reader}

Although virtual child readers of the Alice books are extremely constrained, it does not necessarily mean that real readers will agree to conform to this role and to blindly submit to the textual strategies planned for them. Jean-Jacques Lecercle's ALTER structure, exposed in Interpretation as Pragmatics (1999), posits that reading is not about disclosing the unique meaning of a text, but about ascribing places to different agents. Reading is not about making latent contents manifest or deciphering the author's so-called intention. As is revealed by the arrows indicating power relations in Lecercle's diagram (75), although the Reader is captured at a specific place by the Author and the Text, via the Encyclopaedia and Language, ${ }^{8}$ she can, in turn, capture the Author, via the Text, the Encyclopaedia and Language. Lecercle thinks of this inversion of the active-passive polarity, of this counter-interpretation of the Text and of the Author, in terms of "imposture." As he explains in Interpretation as Pragmatics, he understood the fruitful potential of the concept of imposture after reading Althusser's

\footnotetext{
${ }^{8}$ Lecercle borrows here Eco's concept. As Lecercle reminds us, Eco draws a distinction between the dictionary (which is an ordered "system of lexical semantics in a given language," 207) and the encyclopaedia (which is "a set of loosely structured referential fields" (211), a heterogeneous system of knowledge that speakers share whenever they communicate). According to Lecercle (and Eco before him), no reader can have an unmediated, unfiltered access to the Text she is reading - she always has in mind a diachronically constructed background of encyclopaedic knowledge that helps her to make sense of, interpret and interpellate it.
} 
biography, in which Althusser described how, as a pupil, he copied the teacher's model answer for an assignment which he had already given a few years before in order to pass the exam. As the teacher was unaware of the imposture, Althusser got an excellent grade. Yet, as Lecercle has underlined, this type of imposture is nothing but the identical reproduction of the master's discourse. If young Althusser was, first, under the impression that he had become the master of the master, he then realized that "the only reward for this apparent reversal [was] inexistence" (105). Lecercle then develops the idea that the reader engages in a different sort of imposture, which implies a critical distance from the Text: the dialectics of imposture sheds light on the relationship between a text and the theory that interprets it (97-117). This does not mean that the Impostor Reader ignores the place he has been ascribed in the ALTER structure and refuses to conform to that place, but that acknowledging that he has been captured at a place is an enabling constraint. The Impostor Reader can therefore use, and deliberately misuse, the Text. As Lecercle puts it, "[interpretation] allows, in the guise of the counterinterpellation of imposture, the interpreter a certain latitude to construct the game in which she takes part. On the one hand, she is interpellated at her place by the text, she abides by the rules it imposes on her through an ALTER structure. On the other hand, through imposture, she also constructs those rules, with and against the text - for even the interpellators must be interpellated" (227, my italics). The Impostor Reader consequently fully plays with the text, as she experiences the two sides of play identified by Caillois, ludus and paidia.

Some of the members of what Fish would call the interpretive community of the Alice books regularly play with and against the implicit rules of Carroll's text, ${ }^{9}$ and I would like to argue that the unexpected solutions they suggest to fill in the Carrollian blanks are instances of imposture. Carrollians have in particular amused themselves by giving new endings to the truncated second verse of the Wonderland version of "Tis the voice of the sluggard." Here are some of the alternative answers, reported in the Lewis Carroll's society newsletter, Bandersnatch, and by Martin Gardner in The Annotated Alice (111-112):

When the pie was all finished, the Owl, as a boon,

Was kindly permitted to pocket the spoon:

While the Panther received knife and fork with a growl,

And concluded the banquet by — donning a cowl.

\footnotetext{
${ }^{9}$ The members of this interpretive community are in theory adults and children alike. However, very few child readers' interpretations and interpellations have been recorded and/or published. I nevertheless believe that the following analysis is valid for child readers as well—for reasons discussed below.
} 
taking a trowel.

giving a howl.

giving a scowl.

taking a prowl.

kissing the fowl.

wiping his jowl.

All these solutions do respect some of the rules of Carroll's text, that is to say the metrical rhythm and the rhyme in /avl/, but their authors disregard the content of the verse. These solutions rely on three different types of impostures: the first strategy is to insert jarring elements which are completely out of place in this context, as is the case for the cowl or the trowel-since the Panther is neither a monk, nor a bricklayer. The second strategy is to protract the threatening atmosphere of the verse in order to thwart the reader's expectations and to deprive him of a tragic ending, which is the case for "giving a howl," "giving a scowl" and "taking a prowl." The third strategy consists in reversing the expected ending more explicitly, which is the case for "kissing the fowl" and "wiping his jowl." All these solutions rely on a deliberate disjunction with the subject matter of the poem; hence, the Impostor Readers disobey one of the implicit rules of the poem while abiding by other implicit rules.

According to Lecercle's four theses of interpretation, it could be argued that these solutions are false because they disregard the constraints of the Encyclopaedia or the constraints of the Text (31-32). When impostor readers suggest that "giving a howl," "giving a scowl," "taking a prowl," "kissing the fowl," or "wiping his jowl" could well be endings to the truncated verse, they ignore the rest of the poem, thereby ignoring the Text. When Impostor Readers suggest that "donning a cowl" and "taking a trowel" could also be endings to the truncated verse, they go even further than that since they seem to ignore the Encyclopaedia as well as the Text. And yet, I would like to argue that all these interpretations are "just," to use Lecercle's term; that is, that they conform "to the constraints of the pragmatic structure that governs the interpretation of the text, and (...) [do] not seek to close the interminable process of reinterpretation" (33). They are just because they rely on a different representation of the Author, who exploits the Encyclopaedia in a different way but is coherent with other elements of the Carrollian Text. This Author, captured by the Impostor Reader, does not resort to 
traditional and common models but to their disruption, which is in keeping with many other deliberate disruptions of the shared Encyclopaedia in the Alice books. ${ }^{10}$

\section{“Hold your Tongue!" said the Queen [...]. "I Won't!" said Alice. (AinW, 187)}

What these alternative solutions reveal, then, is that it is possible for a reader to decide not to limit her role to the specific role apparently planned for her by the Author and the Text. Even though the only unusual responses to Carroll's blanks I found were suggested by adult readers, I would like to posit that it is possible for any reader, including child readers, to take on the role of an Impostor Reader who counter-interprets the text, who suggests unforeseen realizations of the text and unexpected ways of filling in the blanks, in other words, a reader who favors full-fledged playfulness combining ludus and paidia over mere ludic adherence to rules. Both Alice books indeed reveal that even a child as mannerly as Alice will learn how to counter-interpellate figures of authority. In Alice's Adventures in Wonderland, although she first agrees to being called Mary Ann and treated like a servant (42), she ends up preventing the White Rabbit from entering his own house (47-48). In Through the Looking-Glass, while the Red Queen and the White Queen keep ascribing the place of a pupil to Alice, she resists and even questions the Queens' right to determine who the guests of her coronation party should be (189). The child reader could accordingly similarly counter-interpellate the Text, which is but another form of authority, and playfully come up with creative alternative answers to these fill-in-the-blank games - answers whose imaginative and counter-interpellative powers should not be underestimated. Hunt reminds us indeed that we should not per se valorize the adult reader's understanding of the Alice books over the child reader's (41), something that (adult) critics and readers tend to do since, as Gubar puts it, "we inhabit a profoundly 'aetonormative' culture, meaning that - however much we profess to adore young people - we generally regard adulthood as the normal and preferred state of being" ("The Hermeneutics of Recuperation" 297). Instead of seeing children as deficient (because of their lack of experience), she advocates what she calls a "kinship model" which invites us both not to minimize the capacities of children and not to magnify the powers and abilities of adultsin particular concerning "adult claims to autonomy and originality" ("Risky Business" 454).

\footnotetext{
${ }^{10}$ For instance, well-known poems such as Isaac Watts's "How doth the little busy bee" or Jane Taylor's "Twinkle Twinkle Little Star" are parodied and respectively become "How doth the little crocodile" and "Twinkle Twinkle Little Bat" in Alice's Adventures in Wonderland, and "criminals" are sent to prison before committing any crime in Through the Looking-Glass.
} 
However, this does not mean that the Impostor (child) Reader will break with the place ascribed to her by the ALTER structure altogether and that she will outright reject the place of the Model Reader at which she is captured by the Author, Language, the Encyclopaedia and the Text. Rather, it means that the (child) reader of the Alice books experiences her nature as a subject of language who can understand language only to the extent that she is submitted to its rules but who can deliberately misuse the rules of language to produce new meanings. The (child) reader's journey around Wonderland and through the Looking-Glass is definitely quite an adventure then: after setting out for a seemingly exciting (paidian) participatory game, she may realize that her role is strictly limited to respecting the ludic rules dictated by the adult author. Yet, reading about Alice's birth as a real subject (subjected to some rules, which she later learns to play with and against) and experiencing both paidia and ludus as a reader make it possible for the (child) reader to renegotiate her relationship with the adult author. Although Gubar feels that the Alice books lead us to believe that "[i]t is grown-ups who control the world of children's fiction" (Artful Dodgers 124), the potential playful counter-interpellations of the Impostor (child) Reader can, in places, shift the power from the adult author to the (child) reader.

\section{Works Cited}

Blake, Kathleen. Play, Games and Sport. The Literary Works of Lewis Carroll. Cornell UP, 1974.

Caillois, Roger. Les jeux et les hommes. Gallimard, 1958.

Carroll, Lewis. Alice's Adventures in Wonderland. D. Appleton and Co., 1866.

---. Through the Looking-Glass. Macmillan, 1872.

---. The Annotated Alice - The Definitive Edition. Alice's Adventures in Wonderland and Through the Looking-Glass, edited by Martin Gardner, The Penguin Press, 2000.

Clark, Beverly Lyon. "Carroll's Well-Versed Narrative: Through the Looking-Glass." Soaring with the Dodo: Essays on Lewis Carroll's Life and Art, edited by Edward Guiliano and James R. Kincaid, University of Colorado, 1982, pp. 65-76.

Collingwood, Stuart Dodgson. The Life and Letters of Lewis Carroll. T. F. Unwin, 1898.

Duflo, Colas. Jouer et Philosopher. Paris: PUF, 1997.

Eco, Umberto. Lector in Fabula - Le rôle du lecteur. Grasset \& Fasquelle, 1985. 
Fish, Stanley. Is There a Text in This Class? Harvard UP, 1980.

Freud, Sigmund. Beyond the Pleasure Principle. New York: Norton, 1961.

Genette, Gérard. Figures III. Seuil, 1972.

Gubar, Marah. Artful Dodgers. Reconceiving the Golden Age of Children's Literature. Oxford UP, 2009.

---. "Risky Business: Talking about Children in Children's Literature Criticism." Children's Literature Association Quarterly, vol. 38, no. 4, Winter 2013, pp. 450-457.

---. "The Hermeneutics of Recuperation: What a Kinship-Model Approach to Children's Agency Could Do for Children's Literature and Childhood Studies." Jeunesse: Young People, Texts, Cultures, vol. 8, no. 1, 2016, pp. 291-310.

Hancher, Michael. The Tenniel Illustrations to the "Alice” Books. Ohio State UP, 1985.

Hunt, Peter. "The Fundamentals of Children's Literature Criticism: Alice's Adventures in Wonderland and Through the Looking-Glass." The Oxford Handbook of Children's Literature, edited by Julia L. Mickenberg and Lynne Valonne, OUP, 2011, pp. 35-51. Iché, Virginie. L'esthétique du jeu dans les Alice de Lewis Carroll. L'Harmattan, 2015.

---. "Submission and Agency, or the Role of the Reader in the First Editions of Lewis Carroll's Alice's Adventures in Wonderland (1865) and Through the Looking-Glass (1871)." Cahiers victoriens et édouardiens, vol. 84, automne 2016, doi : 10.4000/cve.2962. Accessed 12 Apr. 2017.

Iser, Wolfgang. The Implied Reader. The John Hopkins UP, 1974.

---. The Act of Reading. A Theory of Aesthetic Response. Routledge \& Kegan Paul, 1978. Lecercle, Jean-Jacques. Interpretation as Pragmatics. MacMillan Press, 1999.

Marret, Sophie. Lewis Carroll - De l'Autre Côté de la Logique. PU de Rennes, 1995.

Nodelman, Perry. The Hidden Adult. The John Hopkins UP: 2008.

Opie, Iona and Peter Opie. The Oxford Dictionary of Nursery Rhymes. Oxford UP, 1997.

Polhemus, Robert M. "Play, Nonsense, and Games: Comic Diversion". Authoritative texts of Alice's Adventures in Wonderland, Through the Looking-Glass, The Hunting of the Snark; Backgrounds; Essays in criticism, edited by Donald J. Gray, W. W. Norton \& Company, Inc., 1992, pp. 368-372.

Reichertz, Ronald. The Making of the Alice Books - Lewis Carroll's Use of Earlier Children's Literature. McGill-Queen's UP, 1997.

Shavit, Zohar. "The double attribution of texts for children and how it affects writing for children". Transcending Boundaries - Writing for a Dual Audience of Children and Adults, edited by Sandra L. Beckett, Routledge, 2012: pp. 83-97. 
Sundmark, Björn. Alice in the Oral-Literary Continuum. Lund UP, 1999.

Susina, Jan. "Playing Around in Lewis Carroll's Alice Books". American Journal of Play, vol. 2, no. 4, 2010, pp. 419-428.

Sutherland, Robert D. Language and Lewis Carroll. Mouton, 1970.

Sutton-Smith, Brian. The Ambiguity of Play. Cambridge, Massachusetts: Harvard University Press, 1997.

Wintle, Justin and Emma Fisher, editors. The Pied Pipers: Interviews with the Influential Creators of Children's Literature. Paddington Press, 1974.

Wittgenstein, Ludwig. Philosophical Investigations. Blackwell, 2009.

Wong, Mou Lan. "Generations of Re-generation: Re-creating Wonderland through Text, Illustrations and the Reader's Hands". Alice beyond Wonderland: Essays for the Twenty-First Century, edited by Cristopher Hollingsworth, University of Iowa Press, 2009, pp. 135-151. 